Social Sciences Research Journal

DOI: https://doi.org/10.38120/banusad.764164

BANÜSAD, 2020; 3(2), 150-162

\title{
A COMPLICATED RELATIONSHIP BETWEEN FEMINISM AND NEOLIBERAL MULTICULTURALISM
}

\section{Gülen GÖKTÜRK ${ }^{1}$}

\begin{abstract}
The purpose of this article is to analyze feminism's relationship with neoliberalism as an economic program and multiculturalism as a political ideology two of which overlap and complement each other. It discusses how various feminist debates have unfortunately been melted within multiculturalism talk in neoliberal era and how this situation has negatively affected the progress of feminist struggles against patriarchy. Adopting a rather critical approach, this article pinpoints how the shift from redistribution to recognition in neoliberal era transformed feminist claims into a variant of identity politics. Additionally, it takes attention to the degree of patriarchal dominion in private sphere even though neoliberal policies claim to emancipate women in public sphere.
\end{abstract}

Keywords: Feminism, Neoliberalism, Multiculturalism

\section{FEMINIZM VE NEOLİBERAL ÇOKKÜLTÜRCÜLÜK ARASINDA KARMAŞIK BİR İLİŞKİ}

\section{ÖZET}

Bu makalenin amacl, feminizmin, birbiriyle örtüşen ve birbirini tamamlayan ekonomik bir program olarak neoliberalizm ve siyasi bir ideoloji olarak çokkültürlülük ile olan ilişkisini incelemektir. Makale, neoliberal çağda çokkültücülük konuşmalarında çeşitli feminist tartışmaların maalesef nasıl eritildiğini ve bu durumun feminizmin ataerkilliğe karşı mücadelesindeki ilerlemeyi nasıl olumsuz etkilediğini tartışmaktadır. Eleştirel bir yaklaşım benimseyen bu çalışma, neoliberal çağda yeniden dağıtımdan tanınmaya geçişin feminist iddiaları kimlik politikalarının bir varyantına nasıl dönüştürdüğüne işaret etmektedir. Ayrıca, neoliberal politikaların kadınları kamusal alanda özgürleştirdiği iddiasına karşılık, özel alanda ataerkil egemenliğin derecesine dikkat çekmektedir.

Anahtar Kelimeler: Feminizm, Neoliberalizm, Çokkültürcülük

Geliş Tarihi: 04.07.2020

Kabul Tarihi: 03.12.2020

${ }^{1}$ Eskişehir Osmangazi University, Department of Political Science and Public Administration, ggokturk@ ogu.edu.tr 


\section{Sosyal Bilimler Araștırmaları Dergisi}

\section{Social Sciences Research Journal}

DOI: https://doi.org/10.38120/banusad.764164

BANÜSAD, 2020; 3(2), 150-162

\section{Introduction}

In relation to its focus on patriarchy, feminist political theory emphasizes family as the prime arena of political practices. Patriarchy means sexual dominion and it is a powerful ideology of our time. Until the last few decades, most male theorists believed that women had been confined to home and family by their nature and limitations on women's social and political rights were justified by their innate unsuitable position for political and economic activities outside household (Kymlicka, 1990: 239). For the feminists, civil society, rather than the state, is the sphere in which women should concentrate their energies on to encounter male domination (Kantola, 2006: 6). Today much progress has fortunately been achieved and contemporary theorists accept that women and men must be considered alike as free and equal beings who are gifted with self-realization and self-determination. Nonetheless, feminism continues to strive for women's rights, equality and autonomy because despite the presence of anti-discrimination laws in many countries, patriarchy persists.

The purpose of this article is to analyze feminism's relationship with neoliberalism as an economic program and multiculturalism as a political ideology two of which overlap and even complement each other. First, in the 1970s, neoliberalism emerged as a dominant economic program. Until then, feminist movement was particularly focusing on a criticism against male-dominant labor market. Feminist endeavor was echoed in neoliberal politics and masses of women entered job market from then on. On the other side of the coin, neoliberalism was also in need for female labor. Interestingly, this brought new challenges to women because they were now facing other sorts of difficulties including wage discrimination and abuse in job market. Additionally, they were assuming "double shift" inside and outside the house.

The flirt of feminism with neo-liberalism is complicated at two points: first, in neo-liberal era, demands for justice are increasingly settled as claims for the recognition of identity and difference. This shift from redistribution to recognition transforms feminist claims into something that could not be dissociated from identity politics. Accordingly, instead of arriving at a broader, richer paradigm that could comprehend both redistribution and recognition (Fraser, 2009: 108), feminist claims melt within multiculturalism. Second, on one hand, in neo-liberal capitalism the ideal is dual-earner family and thus, women's emancipation is attached to the engine of capitalist accumulation; on the other hand, the liberal idea of liberty sharply separates public sphere from the private and sets strict boundaries in order to prevent any state intervention in private life where feminism leads a struggle (Kymlicka, 1990: 251). 


\section{Sosyal Bilimler Araștırmaları Dergisi}

\section{Social Sciences Research Journal}

DOI: https://doi.org/10.38120/banusad.764164

BANÜSAD, 2020; 3(2), 150-162

Therefore, while neo-liberalism claims to emancipate women in public sphere, it leaves her alone under patriarchal dominion in private sphere. This is a big dichotomy and this public and private distinction in liberalism is a sphere of struggle for the contemporary feminists (Kymlicka, 1990: 250). Departing from these views, feminism's "dangerous flirt" ${ }^{2}$ with neoliberalism and multiculturalism will be discussed from a critical perspective in the rest of the article.

To be clear, contemporary feminist thinking is extremely diverse and feminism itself went through transformation in the course of time. Also, in terms of demands and struggles of feminism in history, first, second and third waves of feminisms can be pinpointed. In this article, the purpose is neither discussing the history of feminism nor explaining the types of feminism. Since feminism is not a fixed and static phenomenon and there is no all-encompassing definition for feminism, any universalizing tendency might create sincere problems for this article. Being aware of this, another objective of this article is not to discuss feminisms but to discuss how various feminist debates have unfortunately been melted within multiculturalism talk in neo-liberal era and how this situation affected negatively the progress of feminist struggles in general. The problem is complicated: individual rights or group rights? Redistribution or recognition?

\section{Female Labor in Neoliberal Economic Program}

When Keynesian economy was replaced by neoliberalism, the role of government being responsible for the general welfare of the people terminated and the notion of individual responsibility arose. From that time on the competitive individual must be responsible for her/his own welfare, and any failure such as poverty or crime is regarded in relation with individual inadequacies. Meanwhile the revolutionary demands of feminist movement are diminished by dominant engines of capitalism to the most widely recognized demand of feminism, namely, paid work for women. Additionally, personal empowerment of individual woman has become much important than any collective movement of women (Eisenstein, 2017: 37). As an interesting coincidence, a certain version of feminism named "Transnational Business Feminism", with its emphasis on individual achievement and competitiveness, emerged at the time of change in economic paradigm.

\footnotetext{
${ }^{2}$ A noun phrase used by Akgöz, Görkem in their article "Mutsuz Evlilikten Tehlikeli Flörte: Feminizm, Neoliberalizm ve Toplumsal Hareketler," Fe Dergi, 8(2), 86-100.
} 


\section{Sosyal Bilimler Araștırmaları Dergisi}

\section{Social Sciences Research Journal}

DOI: https://doi.org/10.38120/banusad.764164

BANÜSAD, 2020; 3(2), 150-162

Adrienne Roberts argues that "Transnational Business Feminism" (TBF) tries to work with neoliberal capitalism rather than challenging it, in contrast to feminists of critical tradition working within socialist, Marxist, post-structural and/or post-colonial traditions. While the former equates women's empowerment with the expansion of capitalism, the latter traditions argue that neoliberalism has created gender-based inequality and oppression (2016: 74). Without problematizing neoliberalism, TBF addresses difficulties faced by women in accessing finance. Roberts names her stance as "healthy skepticism" offering a broader perspective in financial empowerment of women by considering all sorts of inequalities including class and race in distribution of power (2016: 80-81). Therefore, TBF does not criticize neoliberalism itself but it rather tries to expand female space in economy and finance.

Different from TBF, a critical perspective claims that when neo-liberal capitalism introduces women to public arena, it makes them face with new difficulties and inequalities at work and loads her shoulders two burdens. Nowadays, women have double shift meaning they both work at home and in the marketplace. Therefore, neoliberalism, while giving space to women in labor market, surges the degree of their exploitation. In other words, women's dream to be emancipated is restrained by the engine of capitalist accumulation and they are now more alienated to their life than ever before.

Feminism gives a fight for women's rights in many spheres including her working conditions in job market. Nevertheless, this struggle remains inadequate because feminism seems not to be dissociated from multiculturalism's identity and difference politics nowadays. For this very reason, it continues to be fragmented and inefficient for some critical feminist scholars. According to Nancy Fraser, the fate of feminism in the neo-liberal era presents a paradox. While the movement has expanded and spread its ideas across the globe, its criticism against androcentrism (privileging male interests), etatism (bureaucratic professionalism), economism (privileging economic interests) and Westphalianism (nation-state sovereignty) in the previous era now appear as ambiguous claims and assist neo-liberalism in its legitimation needs (2009: 113). And this is exactly what neo-liberalism wants: silencing of any voice of social solidarity.

Multiculturalism, as the ideology of neoliberal economic programs in immigrant countries, talks all about individual and group identities. However, individualism and identity talk divide people when it comes to economic aspects of the social reality. One of the criticisms directed against multiculturalism is that it promotes separatism which disables people to act together. For example, women are suffering from exploitation and inequalities in the market. The disorganized neo-liberal capitalism has declared the dual- 


\section{Sosyal Bilimler Araștırmaları Dergisi}

\section{Social Sciences Research Journal}

DOI: https://doi.org/10.38120/banusad.764164

BANÜSAD, 2020; 3(2), 150-162

earner family ideal type and women have been poured into labor markets around the globe (Fraser, 2009: 110). In this process, women are regarded as cheap labor force. She earns less and her career opportunities are blocked by men. Under today's neo-liberal global capitalism, women face a new form of discrimination and exploitation originating both from men and the system itself but at the same time women's movements as a part of identity politics fell prey to legitimation needs of capitalism. What remedy should be followed to cope with this paradox then? It is not to give up the struggle against the patriarchy for sure. As Fraser claimed, the remedy is to reconnect the struggles against personal subjections to the critique of capitalist system (2009: 115) and exterminate the fragmented opposition.

On the other side of the critical debate, there are feminists like Janet Newman who claim that feminism is not that functional to neoliberalism as Fraser and Eisenstein suggest. She argues that there is a bilateral relationship between feminism and neoliberalism. Neoliberalism in fact had to consider and even adapt feminist projects:

The selective incorporation of gender agendas here can be viewed as a triumph of neo-liberal forms of appropriation of feminist politics... [F]unctionalist readings offer limited purchase on the contradictions at stake in the regendering of the economy and society. In each case, neoliberal projects were themselves transformed - in part-through their encounters with feminist and other activist claims. Employers came to bear the 'costs' of equality governance, parental leave and more complex patterns of work demanded by women's entry as fullworker citizens (Newman, 2013:207).

Newman shows how new contestations are undertaken by women in changing political and governmental atmosphere. She observes that in some spaces of power or in some lines of antagonism such as between state and market or between business efficiency and public benefit, women's role recedes; but also, in some of these contestations new forms of dominance are created (Newman, 2013:211). Therefore, both neoliberalism and feminism benefit from or adapt to one another:

Indeed, just as neoliberalism 'stole' some of the discursive repertoires of feminism and other struggles, so activists sought to appropriate neoliberal repertoires (for example those audit and investment). Politics continued through alternative vocabularies of action (LGTB rather than gay, human rights rather than recognition, migration and asylum rather than race) (Newman, 2013: 213). 


\section{Sosyal Bilimler Araștırmaları Dergisi}

\section{Social Sciences Research Journal}

DOI: https://doi.org/10.38120/banusad.764164

BANÜSAD, 2020; 3(2), 150-162

Different from Fraser and Eisenstein, Newman employs an optimistic approach, but her optimism is not applicable to many countries following neoliberal economic programs with conservative social programs. For example, in Turkey the cut in social welfare reveals a new form of patriarchy. On the one hand the Justice and Development Party (JDP) follows neoliberal policies including large-scale privatization schemes as in the spheres of education and health, on the other hand, the party regards women's role in the familial sphere as a mechanism that would substitute the welfare state. Such an understanding certainly comes from the conservative character of the party. While, women are called to be a member of labour market, the familial/domestic responsibilities are underlined within the femininity. This means that women are invited to consider the risks of work life against their children's welfare, against the integrity of the family, and thus against the social integrity before their deciding to work (Coşar \& Özkan-Kerestecioğlu, 2017: 162-164).

Japanese women's case could represent another striking example. In 1985, equal employment and opportunity law $^{3}$ passed during the time of New Right leader Yasuhiro Nakasone in Japan. Despite the passage of gender equality law in employment, Japanese women continued to face discriminatory practices in workplace. One of the institutional factors responsible for the gap between women and men was the continuing gender roles in society with lack of institutions such as child and elder care centers to assist women in their expected role as caregivers. In relation to that in the late 1980s, Japanese women founded their own labor unions organized by gender rather than occupation. Their objectives were gender equality in workplace and general empowerment of women with rights to self-determination and selfactualization (Zacharias-Walsh, 2016: 1-3). Further, "the equal employment and opportunity law" was revised twice in 1997 and in 2005-2006. However, Japanese firms and public sector, under the intense pressure of neoliberal globalism, have been continuing to stay away from gender-neutral policies. John Holdsworth's BBC documentary "No Sex Please, we are Japanese" (2013) reveals how women decide or are indirectly forced not to get married nowadays in order to get high ranks in their careers. Their situation is an imbroglio since on one hand, men still expect them to assume traditional roles as housewives and on the other hand, companies expect them to prove that they will continue to work as hard as they did when they were single. Marriage, hard-work and childcare all together overwhelm Japanese women so much that they rather prefer to be alone nowadays (See also Belarmino and Roberts, 2019).

\footnotetext{
${ }^{3}$ The Ordinance for the Enforcement of the Act on Ensuring Equal Opportunities for and Treatment of Men and Women in Employment in its full name.
} 


\section{Sosyal Bilimler Araștırmaları Dergisi}

\section{Social Sciences Research Journal}

DOI: https://doi.org/10.38120/banusad.764164

BANÜSAD, 2020; 3(2), 150-162

Neoliberal economy individualizes people and supresses any sort of collective movement. It gives a space for women in job market but exposes them to new sorts of exploitations. This paper does not accept any idea that feminist struggle is totally passive in this process. Certainly, there is some degree of reciprocity in between feminism and neoliberalism, however, this reciprocity diminishes in disadvantage of feminism especially in countries following conservative new right policies and/or having strict traditional values.

\section{Does Feminism Fall Prey to Multiculturalism?}

Like feminism, multiculturalism does not have one single definition. For Marie Macey, multiculturalism is an answer to cultural and religious diversity in society (2009: 1). It is the belief that people in other cultures, foreign and domestic, are human beings, as well and they deserve equal respect and concern, not to be treated like a subordinate caste (Cohen, Howard, Nussbaum, 1999: 4). One of the pundits of multiculturalism Will Kymlicka describes a multicultural state as such:

"The state must be seen as belonging equally to all citizens...A multicultural state repudiates any nation building policies that assimilate or exclude members of minority or non-dominant groups. Instead, it accepts that individuals should be able to access state institutions, and act as full and equal citizens in political life, without having to hide or deny their ethno-cultural identity" (2007: 65).

There are many examples around the world in which the language of multiculturalism and minority rights is employed by local elites to deal with gender and caste inequalities, or to legitimize unfair cultural practices and traditions. According to Kymlicka, multiculturalism could easily be adopted where liberal democracy is already well-established (2007: 6-8). Slavoj Žižek, however, critically affirms that the ideal form of ideology of global capitalism is multiculturalism (1997: 44). Multiculturalism bears diversity as long as cultures are cute and not much visible. Therefore, there is still a power relationship in multiculturalism. Giving Canada as an example, Mary-Jo Nadeau shares a similar view with Žižek from a feminist angle. According to her perspective, Canada's mosaic metaphor erases systemic power relations through over-emphasis on diversity and on hypothesis of a largely unified whole consisted of equal parts. For example, it erases racism with a language of diversity (2009: 9). Further, it erases economic inequalities and any sort of struggles to overcome it. 


\section{Sosyal Bilimler Araștırmaları Dergisi}

\section{Social Sciences Research Journal}

DOI: https://doi.org/10.38120/banusad.764164

BANÜSAD, 2020; 3(2), 150-162

Multiculturalism highlights the inequalities experienced by cultural minorities and feminism the inequalities experienced by women and both commit to equality (Phillips, 2007: 3). The question is whether multicultural policies were the best way to deal with inequalities based on identity, culture and gender in societies. There is a large body of feminist literature exploring the harm given to women by multicultural policies. Such policies encourage public authorities to tolerate hegemonic patriarchal practices within communities (Phillips, 2007: 12). In other words, multiculturalism focuses on differences between, rather than within communities (Macey, 2009: 58). This essentialist view also affects the position of women as they are also selectively labeled and categorized as Muslim women, Indian women, black women, white women and so on.

Related to that, in the late 1980s a very severe public controversy broke out in France about the Magrébin (Maghrebian) girls' attendance to school with their traditional Muslim head scarves regarded as proper clothing for postpubescent young women. The society was divided between those who defended diversity and flexibility and thus sided with these women, those who supported secular education and those who were basically racist and did not approve the situation. In the meantime, the French public was very silent about polygamy among French Arab and African immigrant communities, which was much more crucial. In time however, this situation created a burden for welfare policies of the state and the French government decided to recognize only one wife and considered all the other marriages annulled. The ignorance in the first place created a much bigger problem. What could have been done to terminate the vulnerability of the ignored women and their children? (Okin, 1999: 9-10). This example explains well the possible tensions that might occur between feminism and multiculturalism. This also reveals the tension between group rights and individual rights. Does classic liberalism endanger indigenous values of cultural groups? Shall we provide groups rights to liberal cultural groups and suppress illiberal ones which violate individual rights? How can we objectively decide on whether a group is liberal or not? And how is it possible to overcome patriarchy in society in general?

Multiculturalism considers itself the route to a more respectful and inclusive society because it recognizes diversity of cultures and rejects any sort of assimilation of these by the dominant group. However, it makes the people from other cultures seem more exotic and distinct than they really are (Phillips, 2007: 14). A person believing multiculturalism tolerates cultures to the extent that they remain in their place and be visible in an exotic form only when she/he is interested in them. As Žižek claims, multiculturalism involves condescending Eurocentrist distance and respect for local cultures without roots 


\section{Sosyal Bilimler Araștırmaları Dergisi}

\section{Social Sciences Research Journal}

DOI: https://doi.org/10.38120/banusad.764164

BANÜSAD, 2020; 3(2), 150-162

in one's own culture. That is to say multiculturalism is a denied, self-referential form of racism, a racism with a distance; it respects the other's identity to an extent that the other remains a self-enclosed authentic community towards which a person having multicultural ideology maintains a distance made possible by her/his privileged universal position (1997: 44). As claimed above, one of the problems about multiculturalism is that it identifies a package of cultures that represents each culture as neatly wrapped up (Phillips, 2007: 27). First, cultures do not remain the same; they change over time through interaction with other cultures. Women change too. Second, such an understanding makes invisible the common problems of women and prevents them to act together. Third, prioritization of ethnicity over all other aspects of the person including her/his age, class and sexual orientation justifies the inequalities within the group. Susan Moller Okin warns us about the disparities in power between the sexes in cultural groups. She claims that some more powerful male members of the group are determinant in group's beliefs, practices and interests and in many cases their decisions are antifeminist limiting the capacities of the female members of the group (1999: 12).

Thus, the failure to recognize the minority ethnic communities, like the majority ones, as heterogeneous rather than homogeneous entities shows the discriminating nature of multiculturalism. Practices like forced marriage, sex-selective abortions, honor killings, female genital mutilation, not sending girls to school, forcing them to wear burka along with many other cultural practices can, are and used to be seen as acceptable and any criticism against these practices can be/have been regarded as interference in minority cultures by the proponents of multiculturalism (Macey, 2009: 30-31, 58, 65). This is prioritization of ethnicity and it disregards human rights and women's rights. Some scholars like Chandran Kukathas support multiculturalism over feminism anyway and draw on generally applicable laws to protect women as opposed to Okin who seeks a more comprehensive approach. For him, feminism and multiculturalism are in tension because while feminism's concern is emancipation of women, multiculturalism tries to preserve customs and cultural heritage of minorities. And sometimes customs deny equal dignity of women with men (2001:87). As opposed to Okin, he argues that when these two are in conflict, multiculturalism must come forward. Accordingly, he does not support state intervention in the affairs of minorities because he thinks that such intervention might create a tendency to reproduce the subjects whose behaviors are needed to be controlled. Also, the primacy of any state is to perpetuate its authority, and this is most of the time in disadvantage of women. Groups in the end must survive by their own resources. If they survive it is because individuals accept their authority. If no one was loyal to them, they would fade away (2001: 92, 95). For Oonagh Reitman, however, when it comes to application of 


\section{Sosyal Bilimler Araștırmaları Dergisi}

\section{Social Sciences Research Journal}

DOI: https://doi.org/10.38120/banusad.764164

BANÜSAD, 2020; 3(2), 150-162

their theory to reality, the result both Okin and Kukathas seek to achieve is more or less the same (2005: 227).

In an attempt to find a middle way, Kymlicka, rejects discriminative practices against women in cultural minorities, and supports a more accommodative form of multiculturalism and raises two questions:

1. Are internal restrictions consistent with liberal principles?

2. Should liberals impose their views on minorities that do not accept some or all these principles? (1996: 26).

His answer is simple in addressing these two questions: human rights are primary and then comes the group rights, and the relationship between the two should be handled carefully on a case-by-case basis. This does not mean that the larger society and its institutions are supreme over the indigenous groups' values. Kymlicka warns us to think creatively in order not to undermine the legitimate objections of the group (1996: 29).

What is being discussed so far is while multiculturalism put emphasis on diversity and difference, it assumes that cultures are authentic and good in their nature. However, they might also contain negative elements and harm their members. Additionally, multiculturalism approaches to cultures as they are ungendered; however, they are gendered, and any type of feminism being melted in multiculturalism remains ineffective to deal with women's claims. Preserving cultures are important but individual expectations and salvation cannot be undermined. Most of the time oppressions faced by an individual can only be overcome by collective actions. Feminist struggle needs unity as well. Therefore, policies disrupting collectivity should be taken out of the table in order to retain justice. Also, human rights must prevail group rights, certainly in consideration of vulnerability of each specific case.

\section{Conclusion}

This paper argues that neo-liberalism has changed the terrain on which feminism operated. In neoliberal era the political culture of capitalist societies has altered. On one hand, neoliberalism, while increasing female employment, forces women to double shift. On the other hand, the claims of justice start to be expressed as claims for recognition of identity and difference and feminist discourse gets articulated within multiculturalism language. For critical feminist scholars like Okin, feminism unfortunately has fallen prey to this new political culture and become a variant of identity politics. 


\section{Sosyal Bilimler Araștırmaları Dergisi}

Social Sciences Research Journal

DOI: https://doi.org/10.38120/banusad.764164

BANÜSAD, 2020; 3(2), 150-162

In this article the purpose is not to degrade achievements of feminism in the last few decades. As cited previously, some scholars like Newman claims a two-sided relationship between feminism and neoliberalism and argues that each of them adopts something from another. Therefore, feminism is not that passive in front of neoliberalism as argued by some critical scholars. However, there seems to be an imbalance in favor of neoliberalism in this relationship. For instance, in neoliberal era multiculturalist policies create pitfalls for the feminists to challenge the patriarchy. These pitfalls are fragmentation of social opposition, silencing social movements, ignorance of exploitation in the marketplace and prioritization of culture vis-à-vis other sorts of inequalities including gender, class and age. Further, neoliberalism, when combined with conservatism, is even more dangerous for the feminist achievements so far.

In relation to rise of identity politics in neoliberal era, multiculturalism offers equality between cultures but not within cultures and it remains inadequate to answer questions concerning the negative aspects of cultures. It also seems that multiculturalism tolerates different cultures only from a distance as Žižek claims. Adding to that multiculturalism separates women and women's movements on the basis of ethnic difference. Muslim women and black women are exposed to various other sorts of injustices in addition to the ones their white European origin fellows face but with the fragmented nature of feminism within multiculturalism, it is difficult to achieve progress for the gender equality. In light of these issues, feminists must be aware of any sort of policies aiming to disorganize the struggle against the patriarchy. Additionally, in order to cope with gender inequalities within cultures, human rights must prevail group rights as a general rule, but exceptions must also be considered if needed and each case must be evaluated in itself.

\section{BIBLIOGRAPHY}

Akgöz, G. (2016) “Mutsuz Evlilikten Tehlikeli Flörte: Feminizm, Neoliberalizm ve Toplumsal Hareketler”, Fe Dergi, 8(2): 86-100.

Belarmino, M. and Roberts, M. R. (2019) "Japanese Gender Role Expectations and Attitudes: A Qualitative Analysis of Gender Inequality”, Journal of International Women's Studies, 20(7): 272288. 


\section{Sosyal Bilimler Araștırmaları Dergisi}

\section{Social Sciences Research Journal}

DOI: https://doi.org/10.38120/banusad.764164

BANÜSAD, 2020; 3(2), 150-162

Cohen, J., Howard, M. and Nussbaum, M. C. (1999) "Introduction: Feminism, Multiculturalism and Human Equality” Okin (ed.) Is Multiculturalism Bad for Women? Princeton, New Jersey.: Princeton University Press.

Coşar, S. and Özkan-Kerestecioğlu, İ. (2017) "Feminist Politics in Contemporary Turkey: Neoliberal Attacks, Feminist Claims to the Public”, Journal of Women, Politics \& Policy, 38(2): 151-174.

Eisenstein, H. (2017) “Hegemonic Feminism, Neoliberalism and Womenomics: 'Empowerment' instead of Liberation”, New Formations, 91: 35-49.

Fraser, N. (2009) “Feminism, Capitalism and the Cunning of History”, New Left Review, 56: 97-117.

Holdsworth, J. (2013) “No Sex Please, we are Japanese”, BBC Documentary.

Kantola, J. (2006) "Feminists Theorize the State”, New York: Palgrave Macmillan.

Kukathas, C. (2001) “Is Feminism Bad for Multiculturalism?” Public Affairs Quarterly, 15(2): 83-98.

Kymlicka, W. (1990) “Contemporary Political Philosophy: An Introduction”, Oxford: Oxford University Press.

Kymlicka, W. (1996) "The Good, the Bad and the Intolerable: Minority Group Rights”, Dissent, Summer, 22-30.

Kymlicka, W. (2007) "Multicultural Odysseys: Navigating the New International Politics of Diversity", New York: Oxford University Press.

Macey, M. (2009) “Multiculturalism, Religion and Women: Doing Harm by Doing good?” New York: Palgrave Macmillan.

Nadeau, M. J. (2009) “Troubling Herstory: Unsettling White Multiculturalism in Canadian Feminism”, Canadian Woman Studies/Les Cahiers de la Femme, 27, 2/3: 6-13.

Newman, J. (2013) “Spaces of Power: Feminism, Neoliberalism and Gendered Labor”, Social Politics: International Studies in Gender, State and Society, 20(2): 200-221.

Okin, S. M. (1999) “Is Multiculturalism Bad for Women?” Okin (ed.) Is Multiculturalism Bad for Women? New Jersey: Princeton University Press.

Phillips, A. (2007) “Multiculturalism without Culture”, New Jersey: Princeton University Press. 


\section{Sosyal Bilimler Araștırmaları Dergisi}

\section{Social Sciences Research Journal}

DOI: https://doi.org/10.38120/banusad.764164

BANÜSAD, 2020; 3(2), 150-162

Reitman, O. (2005) "Multiculturalism and Feminism: Incompatibility, Compatibility, or Synonymity?” Ethnicities 5(2): 216-247.

Roberts, A. (2016) "The Limitations of Transnational Business Feminism: The Case of Gender Lens Investing”, Soundings: A Journal of Politics and Culture, 62: 68-83.

Zacharias-Walsh, A. (2016) “Our Unions, Our Selves: The Rise of Feminist Labor Unions in Japan”, Ithaca: Cornell University Press.

Žižek, S. (1997) “Multiculturalism, Or, the Cultural Logic of Multinational Capitalism”, New Left Review, 225: 28-51. 